\title{
Helminths of lizards from the municipality of Aripuanã in the southern Amazon region of Brazil
}

\author{
R.W. Ávila ${ }^{1 *}$ and R.J. da Silva ${ }^{2}$ \\ ${ }^{1}$ Departamento de Ciências Biológicas/CCBS, Universidade Regional \\ do Cariri, R. Cel Antônio Luiz, 1161, CEP 63105-000, Crato, CE, Brazil: \\ ${ }^{2}$ Departamento de Parasitologia, UNESP - Univ. Estadual Paulista, \\ Campus de Botucatu, Instituto de Biociências, Botucatu, São Paulo, Brazil
}

(Received 1 August 2011; Accepted 13 November 2011; First Published Online 14 December 2011)

\begin{abstract}
Ninety-five specimens from 13 species of lizard collected during a herpetofaunal monitoring programme of the Faxinal II power plant, municipality of Aripuanã, state of Mato Grosso, Brazil (southern Amazon region) were examined for helminths. A total of 21 helminth species (16 Nematoda, 1 Cestoda and 4 Trematoda) were recovered, with an overall prevalence of $67.37 \%$. Seventeen new host records and seven new locality records are reported. A low number of specialists and core helminth species were found. Lizard body size was positively correlated with both the total number of helminth species and individuals. Active foragers exhibited higher helminth diversity. However, sit-and-wait foragers, especially Plica plica, had similar diversity values as active foragers and harboured more helminth species. The degree of similarity in helminth fauna was higher among closely related host species.
\end{abstract}

\section{Introduction}

The Brazilian Amazon harbours more than 100 species of lizard (Ávila-Pires, 1995). Despite this diversity, studies on helminths of Amazonian lizards are scarce and basically consist of species descriptions (see Freitas \& Lent, 1938; Alho, 1965; Bain, 1974). However, there has been a recent increase in taxonomic studies and many species, such as Allopharynx daileyi from Uranoscodon superciliosus (Bursey et al., 2005a) and Cosmocerca vrcibradici from Cercosaura eigenmanni and C. oshaughnessyi (Bursey \& Goldberg, 2004) have been described.

There has also been an increase in ecological studies on parasitism and many lizard species have been studied, such as Anolis fuscoauratus (Goldberg et al., 2006a), Anolis punctatus, A. transversalis (Goldberg et al., 2006b), Alopoglossus angulatus, A. atriventris (Goldberg et al., 2007a), Kentropyx calcarata, Leposoma osvaldoi and Potamites ecpleopus (Goldberg et al., 2007b). However, the

\footnotetext{
*E-mail: robsonavila@gmail.com
}

studies cited are restricted to the northern portion of Brazilian Amazon and no investigations have been carried out in the southern Amazon.

The aim of the present study was to analyse the helminth fauna of a lizard community in the municipality of Aripuanã, state of Mato Grosso, Brazil (southern Amazon region).

\section{Materials and methods}

\section{Collection and examination of lizards}

Ninety-five lizards were collected during the herpetofaunal monitoring programme of the Faxinal II hydroelectric power plant $\left(10^{\circ} 9^{\prime} 0^{\prime \prime} S, 59^{\circ} 27^{\prime} 0^{\prime \prime} \mathrm{W}\right)$ in the municipality of Aripuanã (Mato Grosso, Brazil). Captures were carried out using pitfall traps with drift fences and by hand from September 2006 to July 2008. The lizards were euthanized, fixed in a $10 \%$ formalin solution and preserved in $70 \%$ ethanol. Voucher specimens were deposited in the Zoological Collection of the Universidade Federal de Mato Grosso (Brazil). 
In the laboratory, a longitudinal incision was made from the throat to the vent of each lizard specimen and the body cavity, lungs, biliary vesicle and gastrointestinal tract were examined using a dissecting microscope. Helminths were placed in vials with $70 \%$ ethanol for subsequent identification. Nematodes were cleared in phenol and trematodes and cestodes were stained in carmine and cleared with creosote. Species identification was performed with the aid of a computerized image analysis system (Qwin Lite 3.1, Leica Microsystems,

Table 1. Epidemiological data on lizards and respective parasites in the municipality of Aripuanã, Mato Grosso, Brazil. For each host species, the number of specimens examined $(N)$, mean snout-vent length $(\mathrm{SVL})$, prevalence $(\mathrm{P})$, intensity of infection $(\mathrm{I}$, mean \pm SD) and infection sites of each nematode are given.

\begin{tabular}{|c|c|c|c|c|c|c|}
\hline Host & $N$ & SVL & Parasite & $\mathrm{P}$ & I & Site \\
\hline \multicolumn{7}{|l|}{ Iguanidae } \\
\hline \multirow[t]{5}{*}{ Iguana iguana } & 7 & $154.7 \pm 104.8$ & Alaeuris vogelsangi & 14.3 & 34400 & LI \\
\hline & & & Cosmocercidae larvae & 14.3 & & $\mathrm{~L}$ \\
\hline & & & Helicotrema magniovatum $^{\mathrm{b}}$ & 28.6 & $11 \pm 8.5$ & SI \\
\hline & & & Ozolaimus cirratus ${ }^{\mathrm{b}}$ & 14.3 & 12241 & SI, LI \\
\hline & & & Ozolaimus megatyphlon & & $6585 \pm 7786.7$ & LI \\
\hline \multicolumn{7}{|l|}{ Hoplocercidae } \\
\hline Hoplocercus spinosus & 3 & $89.8 \pm 8.6$ & Africana dardanelosi & 100 & $7 \pm 8.7$ & \\
\hline \multicolumn{7}{|l|}{ Polychrotidae } \\
\hline \multirow[t]{5}{*}{ Anolis fuscoauratus } & 4 & $42.9 \pm 3.3$ & Mesocoelium monas ${ }^{\mathrm{a}, \mathrm{b}}$ & 25 & 8 & SI \\
\hline & & & Oswaldocruzia vitti & 25 & 4 & LI \\
\hline & & & Physaloptera retusa & 50 & $3 \pm 1.4$ & $\mathrm{~S}$ \\
\hline & & & Skrjabinellazia galliardia, b & 25 & 2 & LI \\
\hline & & & Strongyluris oscari & 50 & 1 & LI \\
\hline Anolis ortonii & 1 & 42.7 & Not parasitized & - & - & - \\
\hline Anolis phyllorhinus & 1 & 82.3 & Oswaldofilaria sp. ${ }^{\text {a }}$ & 100 & 1 & $\mathrm{BC}$ \\
\hline \multicolumn{7}{|l|}{ Tropiduridae } \\
\hline \multirow[t]{7}{*}{ Plica plica } & 13 & $105 \pm 29.4$ & Mesocoelium monas ${ }^{\mathrm{a}}$ & 15.4 & $6.5 \pm 7.8$ & SI \\
\hline & & & Paradistomum parvissimum ${ }^{\mathrm{a}}$ & 7.7 & & BV \\
\hline & & & Parapharyngodon sceleratus ${ }^{\mathrm{a}}$ & 23.1 & $2.7 \pm 1.5$ & LI \\
\hline & & & Piratuba sp. ${ }^{\mathrm{a}}$ & 7.7 & 1 & LI \\
\hline & & & Physaloptera lutzi $i^{\mathrm{a}}$ & 7.7 & 70 & $\mathrm{~S}$ \\
\hline & & & Physaloptera retusa & 84.6 & $36.7 \pm 38.9$ & S, SI \\
\hline & & & Strongyluris oscari & 69.2 & $18.8 \pm 19.1$ & SI, LI \\
\hline \multirow[t]{5}{*}{ Uranoscodon superciliosus } & 10 & $101.2 \pm 31.6$ & Allopharynx daileyi ${ }^{\mathrm{b}}$ & 40 & $6.5 \pm 6.4$ & SI \\
\hline & & & Mesocoelium monas & 10 & 2 & SI \\
\hline & & & Paradistomum parvissimum ${ }^{\mathrm{a}}$ & 10 & 18 & BV \\
\hline & & & Parapharyngodon sceleratus ${ }^{\mathrm{a}}$ & 10 & 1 & LI \\
\hline & & & Strongyluris oscari ${ }^{\mathrm{a}}$ & 20 & $3 \pm 1.4$ & LI \\
\hline \multicolumn{7}{|l|}{ Gekkonidae } \\
\hline Hemidactylus mabouia & 6 & $56.5 \pm 11.3$ & Parapharyngodon sceleratus & 16.7 & 6 & LI \\
\hline \multicolumn{7}{|l|}{ Phyllodactylidae } \\
\hline \multirow[t]{2}{*}{ Thecadactylus solimoensis } & 3 & $115.5 \pm 26.7$ & Mesocoelium monas ${ }^{\mathrm{a}}$ & 33.3 & 8 & SI \\
\hline & & & Parapharyngodon sceleratus ${ }^{\mathrm{a}}$ & 33.3 & 11 & SI, LI \\
\hline \multicolumn{7}{|l|}{ Sphaerodactylidae } \\
\hline Coleodactylus amazonicus & 4 & $21.9 \pm 0.6$ & Physaloptera retusa ${ }^{\text {a }}$ & 75 & $3 \pm 1.7$ & $\mathrm{~S}$ \\
\hline Gonatodes hasemani & 3 & $33.1 \pm 4.2$ & Not infected & - & - & - \\
\hline \multirow{2}{*}{ Gonatodes humeralis } & 8 & $34.4 \pm 3.4$ & Parapharyngodon sceleratus ${ }^{\mathrm{a}}$ & 37.5 & $1.3 \pm 0.6$ & LI \\
\hline & & & Physaloptera retusa $a^{\mathrm{a}}$ & 25 & $10 \pm 12.7$ & $\mathrm{~S}$ \\
\hline \multicolumn{7}{|l|}{ Teiidae } \\
\hline \multirow[t]{5}{*}{ Ameiva ameiva } & 12 & $113.4 \pm 23.2$ & Oochoristica ameivae ${ }^{\mathrm{b}}$ & 41.67 & $9.2 \pm 10.8$ & SI \\
\hline & & & Parapharyngodon sceleratus & 25 & & LI \\
\hline & & & Physaloptera retusa & 75 & $7.2 \pm 11.9$ & $\mathrm{~S}$ \\
\hline & & & Physalopteroides venancioi & 8.3 & & S \\
\hline & & & Spinicauda spinicauda & 83.3 & $14.9 \pm 32.5$ & LI, SI \\
\hline \multirow[t]{4}{*}{ Kentropyx calcarata } & 10 & $79.3 \pm 16.5$ & Kentropyxia sauria ${ }^{\mathrm{b}}$ & 30 & $11 \pm 14.1$ & SI \\
\hline & & & Oochoristica ameivae ${ }^{\mathrm{a}}$ & 20 & 1 & SI \\
\hline & & & Paradistomum parvissimum ${ }^{\mathrm{a}}$ & 10 & 25 & BV \\
\hline & & & Physaloptera retusa & 60 & $3.7 \pm 4.4$ & $S$ \\
\hline \multicolumn{7}{|l|}{ Gymnophthalmidae } \\
\hline Cercosaura eigenmanni & 2 & $41.1 \pm 0.5$ & Not parasitized & - & - & - \\
\hline \multirow[t]{2}{*}{ Leposoma osvaldoi } & 8 & $29.7 \pm 4.5$ & Cosmocerca sp. & 12.5 & 6 & LI \\
\hline & & & Oswaldocruzia vitti ${ }^{\mathrm{a}}$ & 25 & $2.5 \pm 2.1$ & SI \\
\hline
\end{tabular}

Abbreviations for infection sites: BC, body cavity; S, stomach; LI, large intestine; SI, small intestine; L, lungs.

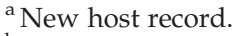

${ }^{\mathrm{b}}$ New state record. 
Wetzlar, Germany). Voucher specimens are deposited in the Helminth Collection of the Instituto de Biociências of the Universidade Estadual Paulista, Botucatu Campus, city of Botucatu, state of São Paulo, Brazil.

\section{Data analysis}

The ecological terms used throughout this text follow Bush et al. (1997). The diversity of the nematode fauna associated with each host species was estimated using Brillouin's diversity index (Magurran, 1988), considering only parasitized individuals. The classification of helminths followed Roca (1993): prevalence values greater than $30 \%$ were considered indicative of core species and values between 10 and $30 \%$ were considered indicative of secondary species. The helminth classification as generalist (not restricted to a single host species) or specialist (in single host species) followed Bursey et al. (2005b). The classification of lizard foraging mode followed Vitt (1991), Vitt \& Zani (1998) and Vitt et al. (2003). The effect of lizard body size was tested by calculating Pearson's correlation coefficients between lizard snout-vent length (SVL) and both the total number of parasites and number of helminth species for each lizard host. The Jaccard index was used for the determination of between-species similarities in the composition of the nematode community using qualitative data only, thereby avoiding comparisons between specimens collected in different areas and seasons. To evaluate the similarity between species, the qualitative data were subjected to unweighted pair group method with arithmetic mean (UPGMA) cluster analysis using Sorensen's coefficient of the Multi-Variate Statistical Package (MVSP version 3.1) (Kovach, 2007).

\section{Results}

A total of 74,167 helminths belonging to 21 species were recovered (16 nematodes, 1 cestode and 4 trematodes). The overall prevalence was $67.37 \%$. The nematodes Physaloptera retusa and Parapharyngodon sceleratus, from the stomach and large intestine, respectively, were found infecting more lizard species (6 each), followed by the trematode Mesocoelium monas, which infected four lizard species (table 1). Among the 41 records, few helminths (36.6\%) were considered core species and the majority were considered secondary species. Physaloptera retusa attained the status of core species in more lizard species (table 1).

Two $(2.1 \%)$ individual lizards with a sit-and-wait foraging mode harboured the most helminth species (4): one Iguana iguana and one Plica plica. Eleven (11.6\%) individual lizards harboured three helminth species (active foragers: six Ameiva ameiva and two Kentropyx calcarata; sit-and-wait foragers: two P. plica and one Anolis fuscoauratus). Another $20 \%$ harboured two helminth species and $33.7 \%$ were infected by only one helminth species.

The highest diversity was found in the teiid A. ameiva $(0.46 \pm 0.32)$, followed by the tropidurid P. plica $(0.36$ $\pm 0.28)$ and the polychrotid A. fuscoauratus $(0.27 \pm 0.36)$ (table 2). However, P. plica was found to harbour more helminth species (7) (table 1).

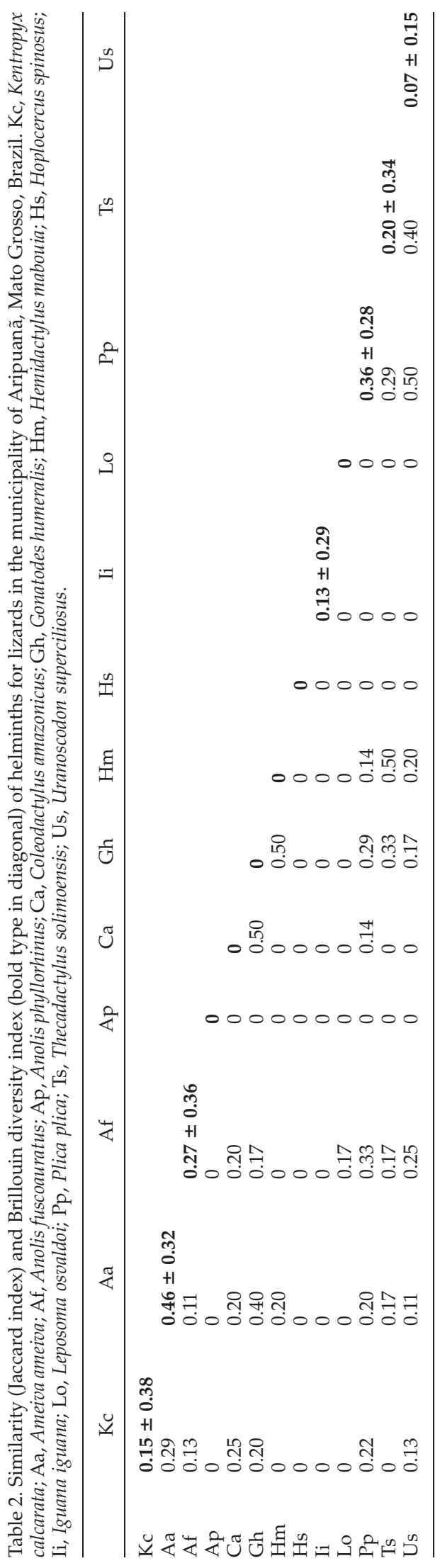




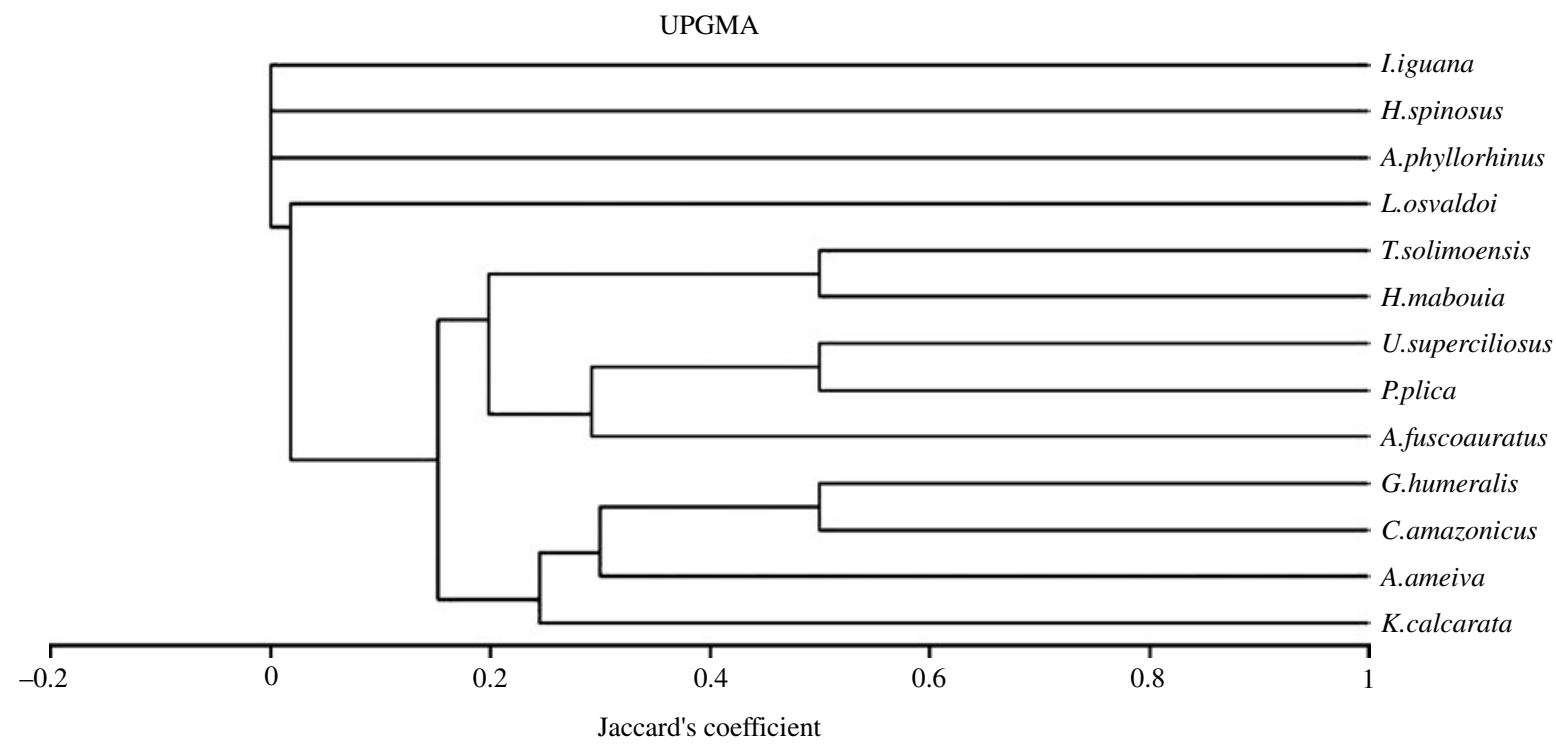

Fig. 1. UPGMA cluster analysis of helminth communities of lizards from the municipality of Aripuanã in the southern Amazon region of Brazil.

Both the total number of helminth species $(R=0.53$, $P<0.001)$ and total number of parasites $(R=0.66$, $P<0.001)$ were correlated with lizard SVL. Similarities in helminth fauna were greater between phylogenetically closer lizard species, such as two pairs of gekkotans (Thecadactylus solimoensis-Hemidactylus mabouia and Gonatodes humeralis-Coleodactylus amazonicus) and the tropidurids P. plica and Uranoscodon superciliosus (fig. 1). Three species (I. iguana, Hoplocercus spinosus and Anolis phyllorhynus) had no similarity in helminth fauna with any other lizard species.

\section{Discussion}

Despite the small sample size for many lizard species, 17 new host records and seven new locality records are reported in the present paper, which can be considered a substantial contribution for the Amazon region. According to Aho (1990), the helminth fauna of reptiles is depauperate in comparison to other vertebrates and is dominated by generalist species. This statement is corroborated by a number of studies carried out in the Neotropical region (e.g. Vrcibradic et al., 2000; Bursey et al., 2005c) as well as the present investigation.

Interesting patterns of helminth richness were observed between lizards with different foraging modes. The highest diversity was found in the active forager $A$. ameiva, followed by the sit-and-wait forager $P$. plica. However, when the total numbers of helminth species per individual and per lizard species were analysed, sit-and-wait foragers tended to harbour more helminths than active foragers. Although Aho (1990) suggests that active foragers tend to harbour a richer and more complex helminth fauna, a number of studies on Brazilian lizards reveal the opposite trend, with tropidurids exhibiting the richest fauna (see Ribas et al., 1998; Vrcibradic et al., 2000). A diversified diet, with higher values of niche breadth, including plant material, and higher percentages of ants may be responsible for this pattern, as found in many tropidurid species (Vrcibradic et al., 2000). Like populations of Tropidurus, lizards of the genus Plica have a diversified diet, involving a greater proportion of ants (Vitt, 1993).

Lizard body size exerts an effect on the diversity and abundance of helminths. This association has been tested in many lizard species (Fontes et al., 2003; Rocha et al., 2003; Anjos et al., 2005). According to Kuris et al. (1980), this relationship is compatible with MacArthur and Wilson's Island Biogeography Theory: hosts may act as islands. Besides providing a larger niche, body size has a substantial impact on other ecological features of lizards, such as diet and habitat use (see Pianka \& Vitt, 2003), thereby influencing the associated helminth fauna.

Similarities in helminth fauna tend to be greater between closely related sympatric lizards (see Aho, 1990; Vrcibradic et al., 2000). Phylogeny has a substantial impact on lizard ecology (Pianka \& Vitt, 2003), which is reflected in the establishment of the helminth community (Poulin, 1997). This may explain the similarities found in the present study and may partially be related to the substantial differences found in I. iguana and H. spinosus, but do not explain the distinction of A. phyllorhynus regarding its helminth fauna. In the latter species, the small sample size may account for the lower degree of similarity and the most depauperate helminth fauna among all the lizard species analysed.

In conclusion, the patterns found in the present study are in agreement with those found in reptiles, i.e. depauperate fauna characterized by many generalist species and greater similarity, likely due to host phylogeny. 


\section{Acknowledgements}

This study received financial support from the Brazilian fostering agency Fundação de Amparo à Pesquisa do Estado de São Paulo (process 06/59692-5). R.W.A. thanks Coordenação de Aperfeiçoamento de Pessoal de Nivel Superior for a grant. The authors would like to thank Marcos André de Carvalho and Ricardo Alexandre Kawashita Ribeiro for kindly providing the lizards for dissection. We also thank Richard Boike for help with the English version.

\section{References}

Aho, J.M. (1990) Helminth communities of amphibians and reptiles: comparative approaches to understanding patterns and processes. pp. 157-195 in Esch, G.W., Busch, A.O. \& Aho, J.M. (Eds) Parasite communities: Patterns and processes. New York, Chapman \& Hall.

Alho, C.J.R. (1965) Sobre uma espécie nova do gênero Diaphanocephalus Diesing, 1851, parasita de lagarto da Amazônia (Dracaena guianensis Daudin) (Nematoda, Strongyloidea). Boletim do Museu Paraense Emilio Goeldi. Zoologia 59, 1-5.

Anjos, L.A., Rocha, C.F.D., Vrcibradic, D. \& Vicente, J.J. (2005) Helminths of the exotic lizard Hemidactylus mabouia from a rock outcrop area in southeastern Brazil. Journal of Helminthology 79, 307-313.

Ávila-Pires, T.C.S. (1995) Lizards of Brasilian Amazônia (Reptilia: Squamata). Zoolochische Verhandelingen, Leiden 299, 706.

Bain, O. (1974) Description de nouvelles filaires Oswaldofilariinae de lezards sud-americains; hypothese sur l'evolution des filaires de reptiles. Bulletin du Museum National d'Histoire Naturele Series 3 138, 169-200.

Bursey, C.R. \& Goldberg, S.R. (2004) Cosmocerca vrcibradici n. sp. (Ascaridida: Cosmocercidae), Oswaldocruzia vitti n. sp. (Strongylida: Molineidae), and other helminths from Prionodactylus eigenmanni and Prionodactylus oshaughnessyi (Sauria: Gymnophthalmidae) from Brazil and Ecuador. Journal of Parasitology 90, 140-145.

Bursey, C.R., Goldberg, S.R. \& Vitt, L.J. (2005a) New species of Allopharynx (Digenea: Plagiorchiidae) and other helminths in Uranoscodon superciliosus (Squamata: Tropiduridae) from Amazonian Brazil. Journal of Parasitology 91, 1395-1398.

Bursey, C.R., Goldberg, S.R. \& Kraus, F. (2005b) Endoparasites in Sphenomorphus jobiensis (Sauria: Scincidae) from Papua New Guinea with description of three new species. Journal of Parasitology 91, 1385-1394.

Bursey, C.R., Goldberg, S.R. \& Parmelee, J.R. (2005c) Gastrointestinal helminths from 13 species of lizards from Reserva Cuzco Amazónico, Peru. Comparative Parasitology 72, 50-68.

Bush, A.O., Lafferty, K.D., Lotz, J.M. \& Shostak, A.W. (1997) Parasitology meets ecology on its own terms: Margolis et al. revisited. Journal of Parasitology 83, 575-583.

Fontes, A.F., Vicente, J.J., Kiefer, M.C. \& Van Sluys, M. (2003) Parasitism by helminths in Eurolophosaurus nanuzae (Lacertilia: Tropiduridae) in an area of rocky outcrops in Minas Gerais state, southeastern Brazil. Journal of Herpetology 37, 736-741.

Freitas, J.F.T. \& Lent, H. (1938) Pesquisas helmintológicas realizadas no estdo do Pará. V. gênero Diaphanocephalus
Diesing, 1851 (Nematoda: Strongyloidea). Memórias do Instituto Oswaldo Cruz 33, 423-432.

Goldberg, S.R., Bursey, C.R. \& Vitt, L.J. (2006a) Helminths of the brown-eared anole, Norops fuscoauratus (Squamata, Polychrotidae) from Brazil and Ecuador, South America. Phyllomedusa 5, 83-86.

Goldberg, S.R., Bursey, C.R. \& Vitt, L.J. (2006b) Parasites of two lizard species, Anolis punctatus and Anolis transversalis (Squamata: Polychrotidae) from Brazil and Ecuador. Amphibia-Reptilia 27, 575-579.

Goldberg, S.R., Bursey, C.R. \& Vitt, L.J. (2007a) Parasite communities of two lizard species, Alopoglossus angulatus and Alopoglossus atriventris, from Brazil and Ecuador. Herpetological Journal 17, 269-272.

Goldberg, S.R., Bursey, C.R., Caldwell, J.P., Vitt, L.J. \& Costa, G.C. (2007b) Gastrointestinal helminths from six species of frogs and three species of lizards, sympatric in Pará State, Brazil. Comparative Parasitology 74, 327-342.

Kovach, W.L. (2007) MVSP - a multi-variate statistical package for Windows, version 3.1. Penthraeth, UK, Kovach Computing Services.

Kuris, A.M., Blaustein, A.R. \& Alio, J.J. (1980) Hosts as islands. The American Naturalist 116, 570-586.

Magurran, A.E. (1988) Ecological diversity and its measurement. Cambridge, Cambridge University Press.

Pianka, E.R. \& Vitt, L.J. (2003) Lizards: Windows to the evolution of diversity. 333 pp. Berkeley, University of California Press.

Poulin, R. (1997) Species richness and parasite assemblages: evolution and patterns. Annual Review of Ecology and Systematics 28, 341-358.

Ribas, S.C., Rocha, C.F.D., Teixeira-Filho, P.F. \& Vicente, J.J. (1998) Nematode infection in two sympatric lizards (Tropidurus torquatus and Ameiva ameiva) with different foraging tactics. Amphibia-Reptilia 19, 323-330.

Roca, V. (1993) Helmintofauna dels reptils. Monografies de la Societat d'Historia Natural de les Balears 2, 65-76.

Rocha, C.F.D., Vrcibradic, D., Vicente, J.J. \& CunhaBarros, M. (2003) Helminths infecting Mabuya dorsivittata (Lacertilia, Scincidae) from a high altitude habitat in Itatiaia National Park, Rio de Janeiro state, Southeastern Brazil. Brazilian Journal of Biology 63, 129-132.

Vitt, L.J. (1991) Ecology and life history of the wide foraging lizard Kentropyx calcarata (Teiidae) in Amazonian Brazil. Canadian Journal of Zoology 69, 2791-2799.

Vitt, L.J. (1993) Ecology and life history of the scansorial arboreal lizard Plica plica (Iguanidae) in Amazonian Brazil. Canadian Journal of Zoology 69, 504-511.

Vitt, L.J. \& Zani, P.A. (1998) Ecological relationships among sympatric lizards in a transitional forest in the Amazon of Brazil. Journal of Tropical Ecology 14, 63-86.

Vitt, L.J., Ávila-Pires, T.C.S., Zani, P.A., Sartorius, S.S. \& Espósito, M.C. (2003) Live above ground: ecology of Anolis fuscoauratus in the Amazon rain forest, and comparisons with its nearest relatives. Canadian Journal of Zoology 81, 142-156.

Vrcibradic, D., Cunha-Barros, M., Vicente, J.J., Galdino, C.A.C., Hatano, F.H., Van Sluys, M. \& Rocha, C.F.D. (2000) Nematode infection patterns in four sympatric lizards from a restinga habitat (Jurubatiba) in Rio de Janeiro state, southeastern Brazil. Amphibia-Reptilia 21, 307-316. 